\title{
Article
}

\section{Needs and expectations of teachers about the Science Museum of Castilla-La Mancha}

\author{
Santiago Langreo
}

After serving the community for seven years, the Science Museum of Castilla-La Mancha (MCCM) has decided to renew itself. In this context, a survey of the needs and expectations of the people to which the museum is dedicated plays a major role for the changes planned to prove successful. Teachers are among the main users of the museum, staying at the core of all teaching-learning processes, and play a role as mediators between science and students.

This paper analyses the judgements made by teachers about various types of events and teaching resources which are normally provided by science museums and, more specifically, the Science Museum of Castilla-La Mancha. Against that backdrop, science (our content), education (our objective) and the democratic participation of teachers will show a clear route to follow if one wants to achieve quality for our institution and its future events.

\section{Highlights}

The first three results, with values in excess of 4.40, assign great value to experimentation, including workshops and laboratories, as well as touring exhibitions, which bring scientific knowledge to farther places, and the objective of science communication and education.

Only $44.6 \%$ of respondents reported knowing or having visited other science museums. Among them, only $27 \%$ know more than two museums.

There is general consensus about the opportunity for museums to increase their quality by improving all their elements, events, resources, activities, etc.

Teachers have great expectations about the resources which they cannot have at their disposal in their schools, or which are difficult to use, such as science laboratories.

An increasingly important role is assigned to practical activities, such as workshops, and further teaching material allowing for better exploitation of static resources in the museum, including active and engaging - and why not, recreational - events.

To improve quality: increased interactivity, greater experimentation during events, and a need to change some of the contents in the museum - in other words, renewal.

The "ideal teacher" would be: teacher, female, less than 44 years old, with a $\mathrm{PhD}$, chair professor but not a senior teacher, member of the management board of the school, and a teacher of a branch of the humanities.

The results should lead to an analysis of the concept of interactivity, its definition in concrete terms and its adaptation to our museum context.

\section{Introduction}

Quality issues, which are currently so widespread among all types of institutions, also play a role in museums. After seven years of activity, the Board of the Science Museum of Castilla-La Mancha has considered implementing some changes to the contents of the museum - primarily exhibition modules and to their form - mainly methods and activities. In addition to that, changes must be completely justified and not based on rash decisions, aiming at quality in all its dimensions of functionality, effectiveness and efficiency. 
The contents of change were variegated, in principle: need to change scientific contents, some of which are almost obsolete; adapting to the needs and new expectations of formal and non-formal education; enhancement of the autotelic character as a recreational offer; and balance to be found in an open and plural offer, promoting the development of a more democratic, critical and fair society.

Once convinced of the need to change, it became clear that improvement and optimisation would be of paramount importance.

In line with Stenhouse's words, for teaching activities to improve significantly, one needs a research tradition, which is accessible to teachers and develops teaching. For that reason, a survey of the needs and expectations of teachers in our region about the Science Museum of Castilla-La Mancha was included among the objectives. By so doing, support was given to such research tradition and the teaching activities taking place in our museum and in the schools visiting our museum were developed.

The Science Museum of Castilla-La Mancha has always aimed primarily at being an educational resource available to the whole teaching community of the region. There is no doubt that teachers, being the main protagonists of the educational process, have a lot to say and to contribute about the improvement of our museum's activities. This survey aimed to collect the opinions of non-university teachers in our region, as well as their judgements on our resources, contents and opportunities.

Any assessment process can be subdivided into various parts or processes, which are mainly the following: data collection, analysis of information to form judgements and, finally, decision-making. It is our belief that this assessment process requires a basis of scientific and methodological rigour, which is perhaps even truer in a scientific context. For that reason, the best way to reach an effective and efficient assessment is deemed to consist of a research programme providing data and opinions with the least possible level of error or bias, and with enough methodological background to take best decisions. On the other hand, a survey like this can constitute an important step forward, both in Castilla-La Mancha and the whole country, in the context of museum education.

\section{The survey}

The objective of this survey is to analyse the needs and expectations of teachers in our region about the Science Museum as a primary educational resource.

The survey can be classified as applied research, given the aim of increasing and improving knowledge, however targeted at change and renewal. The survey is also descriptive from a methodological viewpoint, as it aims to collect the opinions of a well-defined segment of the population on certain concrete aspects.

\section{Objectives}

The survey covered the various events organised by the museum, its educational resources and its current contents. The following objectives were consequently attained:

- Learning the opinions of high school teachers on the potential quality of various events organised by the museum, either current or prospective.

- Learning the potential of educational resources provided by the museum with reference to the teaching and entertainment functions.

- Learning, similarly to above, that potential applied to the contents of various galleries.

- Analysing the assessment or perception of the CLM Science Museum and comparing them with those of other science museums.

- Learning the composition of visiting teachers according to a number of variables: specialisation, experience, gender, etc.

\footnotetext{
${ }^{1}$ The complete survey can be found at the following address: www.jccm.es/museociencias, and at gabinete.didactico1@mccm.jccm.es.
} 


\section{Target and sample}

The target sample consisted of all teachers working in the high schools of Castilla-La Mancha, both public and private. The selected sample pertained to the whole educational sector, as the questionnaire was sent to all high schools in the region, including public and private schools as well as private schools receiving funds from the state.

Every high school in the region received twenty questionnaires by mail. Headmasters were asked to distribute questionnaires among all departments and teachers in general, favouring science departments. At the same time, it was suggested to make the distribution as randomised as possible. As a result, 20 teachers belonging to 326 schools - a total of 6520 - were invited to take part in the survey, and $\mathbf{4 8 2}$ of them returned the questionnaire. The number of respondents can be deemed to constitute a representative sample from a methodological point of view.

\section{The questionnaire}

The form of a closed questionnaire was chosen to collect information. It was drawn up on the basis of the studies published by A. García and others (1989) for the identification of aspects and functions to be developed by museums. At the same time, account was taken of the current structure of the CLM Science Museum and its contents.

The questionnaire was validated with the support of two professors of the University of Castilla-La Mancha, specialised in quality research and research methodology. The teaching staffs of three high schools of the city of Cuenca were also chosen at random to verify the relevance of their answers, such as the type of distribution or composition of the sample.

Items can be subdivided into four groups according to their contents:

- The first group (items 1 to 10) refers to the quality of the various events organised by the museum.

- The second group (items 11 to 23) regards the potential of educational resources with teaching and entertainment functions provided by the museum; two control items were introduced in this group.

- The third group (items 24 to 31) comprises items related to the teaching and entertainment functions of exhibits.

- The fourth group (items 32 to 34) asked respondents to compare the MCCM with other museums they visited.

Teachers could rate each item on the basis of its relevance to quality increase, giving Likert-style answers (from 1: totally disagree to 5: totally agree). Questionnaires were drawn up, circulated and returned in late 2005, from October to December.

\section{Statistical analyses}

Information was processed statistically with the SPSS package (Statistical Package for Social Sciences), version 13.0. The following procedures were implemented:

a) Statistics and descriptions to calculate averages, standard deviation and frequencies.

b) Charts showing item averages and factors.

c) Cronbach's alpha reliability statistics.

d) Factor analysis.

e) T test to verify hypotheses for two independent samples.

f) ANOVA test for more than two independent samples.

\section{General results.}

The results of the questionnaire will now be analysed. The presentation will consider the various dimensions of the survey separately to enable more fruitful considerations. 


\begin{tabular}{|l|l|r|r|}
\hline No. & Items & & \\
\hline A. & Types of events & Avrg. & s.d. \\
\hline 1 & $\begin{array}{l}\text { I3. The MCCM should organise workshops and laboratories and add a more } \\
\text { active dimension to the learning process. }\end{array}$ & 4.46 & .694 \\
\hline 2 & $\begin{array}{l}\text { I7. The MCCM should organise touring exhibitions bringing the museum's } \\
\text { wealth and knowledge to places with fewer resources. }\end{array}$ & 4.43 & .732 \\
\hline 3 & \begin{tabular}{l} 
I6. The MCCM should organise cultural and science communication activities. \\
\hline 4
\end{tabular} & $\begin{array}{l}\text { I9. The MCCM should cooperate with schools to carry out complementary and } \\
\text { after-school activities. }\end{array}$ & .689 \\
\hline 5 & \begin{tabular}{l} 
I4. The MCCM should prepare teaching material for use in schools. \\
\hline 6
\end{tabular} & $\begin{array}{l}\text { I2. The MCCM should enhance programmes and activities devised especially } \\
\text { for the subjects dealt with at the teaching levels related to scientific contents. }\end{array}$ & 4.30 \\
\hline 7 & $\begin{array}{l}\text { I5. The MCCM should promote scientific research in the subjects connected } \\
\text { with the Museum and its Teaching programmes, by establishing research } \\
\text { programmes or cooperating with other institutions. }\end{array}$ & 4.28 & .7617 \\
\hline 8 & $\begin{array}{l}\text { I10. The MCCM should collect, store and restore scientific and relevant } \\
\text { exhibits. }\end{array}$ & 4.16 & .824 \\
\hline 9 & $\begin{array}{l}\text { I8. The MCCM should cooperate with other non-formal educational institutions } \\
\text { to carry out cultural and leisure activities. }\end{array}$ & 4.06 & .798 \\
\hline 10 & I1. The MCCM should enhance its informal educational function. & 4.03 & .844 \\
\hline
\end{tabular}

Table 1. Average score of items (types of events).

\section{Dimension A: types of museum events}

The table below shows the results recorded for events, sorted decreasingly according to their score. While it is apparent that all these museum events are valued positively by teachers, as they are all considered as important elements to increase quality, this sorting will be useful to establish a possible hierarchy or priority of events.

1. The first three results, with values in excess of 4.40, assign great value to experimenting including workshops and laboratories, as well as touring exhibitions, which bring scientific knowledge to farther and culturally poor places, and the objective of science communication and education.

2. With a rating higher than 4.30, respondents pointed out the need for cooperation with schools on complementary and after-school activities, as well as the preparation of teaching material for use in schools. Such material could include support and further study material dealing with both curricular subjects and the activities implemented at the museum.

3. In the 4.20-range, ranking sixth, there is item 2, indicating that the museum should enhance specific activities for curricular scientific subjects, namely activities related to natural sciences, physics, chemistry, geology, biology, etc. and adapted to the various development stages of students and school curricula.

4. With a score in excess of 4.10, research comes to play a key role, either as applied or descriptive, scientific and teaching research. The traditional function of museums, storing and restoring exhibits and knowledge, is equally relevant to teachers.

5. Approximately at level 4.00, with lower scores assigned by teachers, there are cooperation with other non-formal institutions and the enhancement of the informal educational function. Apparently, teachers do not ascribe the same value to activities which primarily complement, enhance, support or compensate for the curricular dimension, ranking higher, and to the traditional function of museums, which is mainly informal. 


\begin{tabular}{|c|c|c|c|c|c|c|}
\hline No. & $\begin{array}{l}\text { EDUCATIONAL RESOURCES } \\
\text { Functions: }\end{array}$ & $\begin{array}{l}\text { Teach } \\
\text { potent }\end{array}$ & & $\begin{array}{l}\text { Enter } \\
\text { t pote }\end{array}$ & $\begin{array}{l}\text { ainmen } \\
\text { tial }\end{array}$ & No. \\
\hline & & Avrg. & s.d. & Avrg. & s.d. & \\
\hline 1 & $\begin{array}{l}\text { I16. Workshops complementing temporary } \\
\text { exhibitions }\end{array}$ & 4.10 & .835 & 3.97 & .947 & 5 \\
\hline 2 & I13. Teaching material: didactic cards, etc. & 4.06 & .887 & 3.43 & 1.034 & 12 \\
\hline 3 & I20. Moving planetarium & 4.02 & .860 & 4.05 & .895 & 2 \\
\hline 4 & I21. Astronomical observations & 3.99 & .876 & 4.13 & .889 & 1 \\
\hline 5 & I18. Astronomy courses & 3.98 & .811 & 3.99 & .851 & 4 \\
\hline 6 & I17. Specific (ad hoc) workshops, itineraries & 3.98 & .889 & 3.91 & .900 & 6 \\
\hline 7 & I19. Planetarium productions & 3.93 & .793 & 4.03 & .843 & 3 \\
\hline 8 & $\begin{array}{l}\text { I22. Educational innovation programmes: } \\
\text { "Expericiencia" (experi-science) }\end{array}$ & 3.93 & .871 & 3.66 & .977 & 10 \\
\hline 9 & I11. Guided tours of the Museum & 3.92 & .913 & 3.73 & .940 & 8 \\
\hline 10 & I15. Temporary exhibitions & 3.88 & .831 & 3.81 & .842 & 7 \\
\hline 11 & I12. Permanent exhibitions & 3.69 & .832 & 3.49 & .885 & 11 \\
\hline 12 & I23. Website of the museum & 3.67 & .909 & 3.69 & .902 & 9 \\
\hline 13 & I14. Conferences and round tables & 3.52 & .939 & 3.13 & 1.063 & 13 \\
\hline
\end{tabular}

Table 2. Average score of items (educational resources).

\section{Dimension B: educational resources of Science Museums}

Moving on to the analysis of the second dimension, the educational resources used by the Science Museum of Castilla-La Mancha are present in most museums, so that they are known to a vast majority of teachers. These are represented in items 11 to 23 , for which two functions are assessed: teaching and entertainment potential. In other terms, teachers assessed the ability of our museum resources to obtain significant learning results and to entertain, and subsequently, their educational and recreational dimensions. Table 2 indicates the various resources, sorted according to their first function, the educational one. The right column shows the ranking position measured according to the recreational function.

First of all, the results show consistency as in this case it is item 16 the one ranking highest (4.10), namely workshops and laboratories which are again considered as the event - and educational resource, in this case - which is most appreciated for its educational potential. With scores higher than 4, items 13 and 20 follow, with the teaching material standing out (4.06) although not receiving the same score for its recreational potential $\left(12^{\text {th }}\right.$ position). The moving planetarium, at 4.02 , features good educational and recreational potential at the same time $\left(2^{\text {nd }}\right)$.

Secondly, the educational potential of six items was valued more than 3.90. Among those six, three relate to astronomy and the planetarium, astronomical observations recording the highest score, including in connection with their recreational potential ( ${ }^{\text {st }}$ position). Specific workshops appear again, as do educational innovation programmes and guided tours, ranking $8^{\text {th }}$ and $9^{\text {th }}$ respectively (with similar scores for their recreational potential $-10^{\text {th }}$ and $8^{\text {th }}$ position).

Thirdly, ranking tenth with a score of 3.88 , there are temporary exhibitions $\left(7^{\text {th }}\right.$ position for their recreational potential). At a certain distance, items 12 and 23 - permanent exhibitions and the website of the museum - feature scores of 3.69 and 3.67 , with a similar position on the recreational potential ranking $\left(11^{\text {th }}\right.$ and $\left.9^{\text {th }}\right)$.

The last position for both educational and recreational potential is occupied by item 14 , conferences and round tables, scoring 3.52 .

Three resources stand out for the significant differences they reveal (more than three positions in ranking) between educational and recreational potential. These are: workshops complementing exhibitions $\left(1^{\text {st }}\right.$ and $\left.5^{\text {th }}\right)$; teaching material $\left(2^{\text {nd }}\right.$ and $\left.12^{\text {th }}\right)$; and planetarium productions $\left(7^{\text {th }}\right.$ and $\left.3^{\text {rd }}\right)$. Among them, teaching material can be highlighted as a resource presenting great educational potential, according to responding teachers, but not entertaining enough. The results seem to imply that the offer of this type of pencil-and-paper material is necessary as a complement of the various activities organised by the museum, although it difficultly performs a recreational function. 


\begin{tabular}{|l|l|r|r|r|r|r|}
\hline No. & EXHIBITION MODULES, MCCM & \multicolumn{2}{|l|}{$\begin{array}{l}\text { Teaching } \\
\text { potential }\end{array}$} & \multicolumn{2}{l|}{$\begin{array}{l}\text { Entertainme } \\
\text { nt potential }\end{array}$} & No. \\
\hline & & Avrg. & \multicolumn{1}{l|}{ s.d. } & Avrg. & \multicolumn{1}{l|}{ s.d. } & \\
\hline 1 & 3. Planetarium & 4.04 & .770 & 4.11 & .777 & 1 \\
\hline 2 & 2. Astronomy & 3.79 & .832 & 3.78 & .814 & 2 \\
\hline 3 & $\begin{array}{l}\text { 4. "Cronolanzadera" (time shuttle) and Treasures } \\
\text { of the Earth (geology and palaeontology) }\end{array}$ & 3.51 & .928 & 3.47 & .967 & 4 \\
\hline 4 & 5. Life laboratory (environmental sciences) & 3.44 & .935 & 3.40 & .957 & 5 \\
\hline 5 & 6. History of the Future (biology) & 3.40 & .923 & 3.35 & .958 & 6 \\
\hline 6 & $\begin{array}{l}\text { 1. Entrance hall and distribution area, with Time } \\
\text { Machine }\end{array}$ & 3.32 & .991 & 3.58 & .997 & 3 \\
\hline
\end{tabular}

Table 3. Average score of items (exhibition modules).

\section{Dimension C: contents and exhibition modules of the MCCM.}

Although the aspects which are most relevant to our research can be found among the first 23 items, analysed above, it is in any case interesting to study the data pertaining to items 26-31, which relate to the contents of the Science Museum of Castilla-La Mancha and were answered only by teachers who had visited the museum at least once, i.e. about $50 \%$ of the sample.

Looking at table 3, data prove consistent again on the assessment of astronomical contents, which are the modules receiving the highest scores (4.04 and 3.79), similar to those found for previous dimensions of the survey.

Astronomy contents are followed by the three permanent exhibition galleries, which keep the same order as to educational and recreational potential, with geology and palaeontology at a higher level than biology. Lastly, the time machine was assessed as the least educational item, although it ranks third in terms of entertainment. Note should be taken that the score achieved in permanent exhibitions dimension B of the questionnaire (educational resources) - amounted to 3.69, a result higher than that obtained from the respondents who visited the museum: that could be viewed as an index or predictor of the score in the assessment of the MCCM if compared with other science museums.

With reference to the last aspect considered by the survey - comparative assessment of the MCCM with other science museums - it must be indicated that only $44.6 \%$ of respondents reported knowing or having visited other science museums. Among them, only 27\% knew more than two museums (Cosmocaixa, Parque de las Ciencias in Granada and Príncipe de Asturias in Valencia are those cited most frequently).

An analysis of results, and of the average recorded for item 33 (comparative assessment of the MCCM with other science museums, at 2.30), leads to the conclusion that the general opinion on our regional museum is poor, definitely susceptible of improvement, as the scores achieved are lower than those of other national museums.

In that connection, a summary of suggestions made in the questionnaires should be given here. The most frequently recommended change or improvement regards an increase of interactivity, followed by experimentation and a change in the various contents. These three recommendations account for $85 \%$ of contributions, with the rest pointing to the need for a greater offer of teaching material, better information for schools, touring activities and improved guided tours.

\section{Internal consistency}

A Cronbach's alpha reliability coefficient of 0.934 was recorded, which indicates a high level of reliability for the sample.

Interestingly, the reliability coefficient mentioned was calculated on items 1 to 23 (note that items 14 to 23 included two answers, $a$ and $b$ ). However, if the statistical test is carried out on all items of the 
questionnaire, although there are fewer respondents, the coefficient rises to 0.944 . In both cases, a high level of reliability and internal consistency is shown.

\section{Factor analysis}

After carrying out the analyses shown, the relevant factor analysis was conducted. 8 components were obtained, which can be ascribed to various dimensions or sectors: academics, informal, astronomy, etc. Given the purpose of this ad hoc questionnaire, further analyses were not deemed necessary (asymmetry indices, multiple kurtosis, difference tests, etc.). In any case, it was verified that, for most components, theoretical groupings matched with the results obtained from the factor analysis.

\section{Tests to verify differences among averages}

\section{On the basis of specialisation}

At this point of the research, the various relations among independent variables were verified, the first of which relates to the specialisation of teachers. If most teachers attending our museum belong to scientific branches, such as biology, physics, chemistry, etc., it is only appropriate to verify whether the assessments obtained from our questionnaires for this variable are somehow biased: in other words, whether major differences can be found between the opinions of humanities teachers and those of science teachers.

To that end, the $t$ test was carried out to verify differences among averages for two independent samples, with a reliability level of $95 \%$. The results show that humanities teachers give higher scores to 28 items; science teachers value only 8 items more than humanities teachers, although differences are significant only in two cases ( $a 1$ and $a 6$ ). Both refer to informal education activities, explicitly in the first case and implicitly in the second one, where cultural and science communication activities are assessed. Obviously, the scores given by humanities teachers are higher in both cases.

\section{On the basis of remaining variables}

Finally, an analysis of differences among averages distributed among independent variables (gender, age, training, seniority, etc.) was deemed appropriate and carried out with tests to verify hypotheses: $\mathrm{t}$ test for two independent samples and ANOVA test for more than two. The analyses conducted show the profile of teachers with the highest expectations about the museum, as an educational and leisure resource. The "ideal teacher" would be a teacher, female, less than 44 years old, with a $\mathrm{PhD}$, chair professor but with less than 10 years' seniority, member of the management board of the school. Moreover, the ideal teacher would certainly be specialised in humanities. However, the description would be reliable if major differences had proven more frequent. Only the gender variable showed a sufficiently interesting number of differences.

\section{Conclusions}

It was noted that internal assessment processes in museums are reduced to a minimum. They are basically limited to counting the number of visitors and correlating such data with those provided by tourism offices, chambers of commerce, etc.

The survey led to a general idea: there is general consensus about the opportunity for museums to increase their quality by improving all their elements, events, resources, activities, etc. At the same time, the following conclusions could be drawn. They are presented in order of importance, starting from types of events:

1. High school teachers attribute particular value to doing experiments, to be carried out in workshops and laboratories, as the most necessary event, to which positive expectations are attached. Such activities would be followed by a touring provision of events of this kind, also 
taking account of science communication (new researches, new technologies, etc.), which is also a much appreciated function.

2. Teachers also feel that museums need to offer complementary and after-school activities, as well as activities connected with the curricular contents of the various teaching levels and related to the scientific context.

3. With lower scores than the above, teachers value research (making researches at the museum)either scientific and applied or related to teaching - and traditional storing and restoring functions as necessary elements.

4. Informal events and other non-formal activities resulting from institutional forms of cooperation (expositions, conferences, curses, etc.) rank last, although they are still valued positively by teachers.

As far as educational resources are concerned, teachers again give the highest scores to activities carried out in workshops and to teaching material, although the latter ranks low as to its recreational value: that result suggests the need to develop teaching materials such as cards, exercise books, etc. which are attractive enough and entertain besides teaching.

Subsequently, all aspects related to astronomy, observations, the planetarium, etc. are assessed very positively, in connection with both their educational and recreational functions, appearing as a really balanced resource.

Specific workshops, educational innovation programmes and guided tours rank lower, followed by temporary exhibitions, permanent exhibitions and the website of the museum. Conferences and round tables rank last.

Apparently, then, teachers hold great expectations about the resources, which they cannot have at their disposal in their schools, or which are difficult to use, such as science laboratories. At the same time, they give lower scores to resources which are part of traditional museum offers, such as static knowledge and popularisation exhibits, and activities which can be easily implemented in any school, such as conferences and round tables - again at student, non-expert level. In any case, an increasingly important role is recognised for practical activities, such as workshops, and further teaching material allowing for better exploitation of static resources in the museum, including active and engaging - and why not, recreational - events.

Focussing on the exhibition modules of the Science Museum of Castilla-La Mancha, it was found out thanks to $50 \%$ of our respondents - that our museum can definitely be improved, and that the galleries needing most upgrading are "History of the Future" (biology) and the "Life laboratory" (environmental sciences), which are those receiving the lowest scores and those most frequently cited in the recommendations for content change.

Of special note is certainly the fact that a high percentage of teachers have visited no science museum at all: a half of the sample. Such figure is clearly alarming, both for science museum managers and for the educational Administration. However, recommendations given by a number of teachers show a clear route to follow if one wants to improve quality: increased interactivity, greater experimentation during events, and a need to change some of the contents in the museum - in other words, renewal.

Finally, after analysing the relations among all variables, the profile of a so-called "ideal teacher" was created (this profile means a teacher with great expectations about science museums in general and our museum in particular). The "ideal teacher" would be: teacher, female, less than 44 years old, with a PhD, chair professor but not a senior teacher, member of the management board of the school, and - contrary to forecasts - a teacher of a branch of the humanities. All these data should be interpreted with due caution, as the gender variable was the only one with a sufficient number of significant differences. The profile, however, can constitute an interesting point for consideration and suggest a change in the target audience of our educational and cultural resources.

To sum up, what is clear from the survey is that the Science Museum of Castilla-La Mancha needs to change and improve the quality of its contents and the way in which it interacts with its users. Some permanent exhibition galleries or parts of them need to be renewed, as do strategies for action and interaction with the public. Similarly, this change must take account of a number of basic assumptions, founded mainly on increased experimentation and interactivity to achieve a high-quality offer for the museum.

The fact that the Science Museum of Castilla-La Mancha has opted for this self-assessment and applied research process undoubtedly constitutes a new step forward in the internal development of our cultural 
and educational institution, and there is no doubt that it all could open up a new line of action for improvement and optimisation in other museums too, not only in the scientific sector but also in art, archaeology and ethnography, or in any other institution aiming at Education for citizens.

\section{New lines for research}

This work opens up new lines for research. Short-term ones and, as was suggested at the beginning of this paper, those targeted at the assessment and subsequent improvement of our institution will be addressed specifically.

For this reason, the subsequent research line - or second stage of this work - will entail an analysis of the opinions of visitors and other users of the museum, people belonging to any category, organised groups of elderly people, students, etc. The questionnaire will obviously be submitted to primary education teachers, too. A comparative analysis will have to be made with this survey and the results achieved, in order to verify the consistency of our conclusions with an eye on quality in all its dimensions of functionality, effectiveness and efficiency.

The second research line should lead to an analysis of the concept of interactivity, its definition in concrete terms and its adaptation to our museum context. In this connection, starting from the results of other papers, such as the one by Laura Solanilla ${ }^{\mathfrak{b}}$ on new technologies, a structure defining and forming interactive experiences in our context will have to be created or established, so as to provide an interactive offer, which goes beyond hands-on activities or even personal experiences.

As a part of this self-assessment process, and close to the research-action model, the Science Museum of Castilla-La Mancha, as other modern science centres and museums, needs to be open to a cyclical and permanent process of optimisation and improvement, entailing an analysis of resources - not only museum resources, but also personal, material and infrastructure resources - both in management and administration and in the organisation and implementation of various plans, programmes and projects.

To conclude, our thanks go to all those persons and institutions which have been fully supporting this work from the outset: teachers of primary and secondary schools, the Culture and Sport Foundation of Castilla-La Mancha, the Education and Science Council of Castilla-La Mancha, the University of Castilla-La Mancha, and the staff of various Museums throughout Spain. We would also like to thank Dr. Agustín Bayot for his invaluable advice and guidelines on this research.

\section{References}

[1] V. Álvarez, Diseño y Evaluación de Programas, Madrid, EOS (2002).

[2] T. Ambrose, Education in Museums, Museums in Education (Scottish Museums Council) (1987).

[3] C.S. Brembeck and T.J. Thompson, New Strategies for Educational Development. The Cross Cultural Search for Nonformal Alternatives, Lexington, Heath and Company (1973) (Spanish version in 1976).

[4] M.I. Bordas, Estrategias de evaluación de los aprendizajes centradas en el proceso, Revista Española Pedagogía 210 (2001) 5.

[5] J. Cardona, Metodología innovadora de evaluación de centros educativos, Madrid, Sanz y Torres (1994).

[6] A.J. Colom, La pedagogía urbana, marco conceptual de la ciudad educadora, Barcelona: Ajuntament de Barcelona (1990).

[7] A.J.Colom, Estrategias metodológicas en educación no formal, Barcelona Ceac (1992).

[8] A.J.Colom, La calidad de la educación desde la teoría pedagógica y la historia, Bordón 40, No. 2, Madrid (1988).

[9] P.H. Coombs, La crisis mundial de la educación. Perspectivas actuales, Madrid, Santillana (1985).

\footnotetext{
${ }^{2}$ Laura Solanilla Demestre is in charge of Internet communication at the Culture Institute of Barcelona. In her paper " $i$ Qué queremos decir cuando hablamos de interactividad?" (What do we mean by interactivity?), she studies the websites of history and archaeology museums (2002).
} 
[10] A. De la Orden, La calidad de los centros educativos, asunto para un congreso, Bordón 40, No. 2 (1988) Madrid.

[11] J. García, Actividades complementarias en los centros escolares y asociaciones de padres de alumnos, Bordón 42 (1990) 411.

[12] J.V. Merino, Funciones de la evaluación en la evaluación de programas de animación sociocultural, Revista Española de Pedagogía 207 (1997) 337.

[13] M.I. Pastor, La oferta educativa museística destinada a las personas mayores. Tendencias actuales, Revista Española de Pedagogía 226 (2003) 527.

[14] R.G. Paulston, Nonformal Education, an Annotated Internacional Bibliography, New York, Praeger (1972).

[15] A. Ponce de León, Reflexiones y conclusiones sobre el tiempo libre y los valores, Bordón 49 (1997) 87.

[16] J.M. Puig and J. Trilla, La pedagogía del ocio, Barcelona, Alertes (1987).

[17] J. Sarramona, La educación no formal, Barcelona, Ceac (1992).

[18] J. Sarramona, A. Colom and G. Vázquez, Educación no formal, Barcelona, Ariel (1998).

[19] L. Solanilla, ¿Qué queremos decir cuando hablamos de interactividad? El caso de los webs de los museos de historia y arqueología, UOC Revista digital d'humanitats (2002).

[20] J. Strand, The Accessible Museum, Washington D.C., American Association of Museums (1992).

[21] J. Sureda and J. Trilla, Pedagogía ambiental, Barcelona, Ceac (1989).

[22] J. Touriñán, Análisis teórico del carácter formal, no formal e informal de la educación, Papers d'educació No. 1 (1983).

[23] J. Trilla et al., La educación fuera de la escuela, Ámbitos no formales y educación social. Barcelona, Ariel (2003).

[24] J. Trilla, La educación informal, Barcelona, PPU (1986).

[25] J. Trilla, Otras educaciones, Barcelona, Anthropos (1993).

[26] G. Vázquez, La educación no formal y otros conceptos próximos, Barcelona, Ariel (1998) pp. 11-15.

\section{Author}

Santiago Langreo. Teacher and Pedagogue. He began to teach in 1989, first in primary and then in secondary schools. At present he is tutor in a High School and works as pedagogic adviser in the Educational department of the Science Museum of Castilla-La Mancha. He is also psychopedagogy teacher at Castilla-La Mancha University. He is writing his doctoral thesis in non-formal education in science museums. E-mail: gabinete.didactico1@mccm.jccm.es. 